\title{
A monogenean fish parasite, Gyrodactylus chileani n. sp., belonging to a novel marine species lineage found in the South-Eastern Pacific and the Mediterranean and North Seas
}

\author{
Marek S. Ziętara • Dar'ya Lebedeva • \\ Gabriela Muñoz $\cdot$ Jaakko Lumme
}

Received: 14 March 2012/ Accepted: 5 June 2012

(C) The Author(s) 2012. This article is published with open access at Springerlink.com

\begin{abstract}
Gyrodactylus chileani n. sp. is the first Gyrodactylus species reported from Chile. It is an ectoparasite living on fins and skin of a small fish, the Chilean tidal pond dweller Helcogrammoides chilensis (Cancino) (Perciformes: Tripterygiidae). A phylogenetic analysis based on 5.8S+ITS2 of rDNA placed the new species close to marine Gyrodactylus species found in Europe: G. orecchiae Paladini, Cable, Fioravanti, Faria, Cave \& Shinn, 2009 on gilthead seabream Sparus aurata L. from the Adriatic and Tyrrhenian Sea fish farms (Perciformes: Sparidae), and an undescribed species on the black goby Gobius niger L. from the
\end{abstract}

M. S. Ziętara ( $\bowtie)$

Department of Molecular Evolution, University of Gdańsk, Wita Stwosza 59, 80-308 Gdańsk, Poland e-mail: marek.zietara@biol.ug.edu.pl

\section{Lebedeva}

Institute of Biology, Karelian Research Centre, RAS, Pushkinskaya 11, Petrozavodsk, Republic of Karelia,

Russia

e-mail: daryal78@googlemail.com

\section{G. Muñoz}

Facultad de Ciencias del Mar y de Recursos Naturales, Universidad de Valparaíso, Casilla 5080, Reñaca,

Viña del Mar, Chile

e-mail: gabriela.munoz@uv.cl

\section{J. Lumme}

Department of Biology, University of Oulu, P.O. Box 3000, 90014 Oulu, Finland

e-mail: jaakko.lumme@oulu.fi
North Sea (Perciformes: Gobiidae). A morphological description of the latter species is unavailable. These geographically distant parasite samples on different host families form a new well supported Gyrodactylus orecchiae lineage. Using molecular phylogenetics, it is shown that the marine species groups of Gyrodactylus may have a worldwide distribution.

\section{Introduction}

The monogenean flatworm genus Gyrodactylus Nordmann, 1832 is one of the most species-rich genera. The number of described species was 409 in the latest checklist (Harris et al., 2004; see also GyroDB http://www.gyrodb.net/), but the real number of species is estimated to be about 20,000 (Bakke et al., 2002), which is certainly an underestimate if the resolution of molecular methods is utilised and the classical criteria for delineating species are retained (Ziętara \& Lumme, 2003).

Malmberg (1970) subdivided the genus into six subgenera. Two of these subgenera remain perfectly valid, i.e. those infecting Eurasian freshwater fish G. (Limnonephrotus) Malmberg, 1964 and G. (Gyrodactylus) Nordmann, 1832. The four other subgenera (Metanephrotus Malmberg, 1964, Mesonephrotus Malmberg, 1964, Neonephrotus Malmberg, 1964 and Paranephrotus Malmberg, 1964) are on the other hand paraphyletic or polyphyletic using molecular criteria (Matějusová et al., 2003; Vanhove et al., 2011). 
The genus itself is not monophyletic and it is recognised to be a catch-all taxon within the Gyrodactylidae Beneden \& Hesse, 1864 (Kritsky \& Boeger, 2003). The genera: Acanthoplacatus Ernst, Jones \& Whittington, 2001, Diplogyrodactylus Přikrylová, Matějusová, Musilová, Gelnar \& Harris, 2009, Fundulotrema Kritsky \& Thatcher, 1977, Gyrdicotylus Vercammen-Grandjean, 1960, Gyrodactyloides Bykhovskiy, 1947 and Macrogyrodactylus Malmberg, 1957, subgenera and species groups or single species, are all paraphyletic within the family Gyrodactylidae (see Vanhove et al., 2011).

The mechanism resulting in such a phylogeny is the basal radiation of Gyrodactylus (sensu lato) generating new species groups, some marine, some freshwater, and some inhabiting both environments. The latter are perhaps the most interesting, and include examples where the host lineage has moved from marine to freshwater, and the parasite has followed. The best known examples are two species, G. lotae Gusev, 1953 and G. alexgusevi Ziętara \& Lumme, 2003, on the freshwater burbot Lota lota (L.), a gadid, and two species, G. hrabei Ergens, 1957 and G. mariannae Winger, Hansen, Bachmann \& Bakke, 2008, on an inland cottid, Cottus poecilopus Heckel, in Europe. The nearest relatives of all four of these species are parasites of marine hosts (Ziętara \& Lumme, 2003; Rokicka et al., 2009).

To enlarge the geographical range of the Gyrodactylus spp., we describe the first Gyrodactylus species from Chile, which was among 215 fish ectoparasitic species listed by Muñoz \& Olmos (2007). Two other records of Gyrodactylus spp. on small intertidal fishes found in rocky areas, Scartichthys viridis (Valenciennes) (see Muñoz \& Randhawa, 2011) and Sicyases sanguineus Müller \& Troschel (see Muñoz \& Zamora, 2011), await molecular analyses and further description. The species described below is also the first molecularly defined Gyrodactylus reported from the Southern Pacific. Together with two other species of Gyrodactylus from Europe, which are related by ITS rDNA, it forms a new marine species group, which has crossed the equator during its evolutionary history.

\section{Materials and methods}

Fish were collected from rocky pools during low tides in July, 2009. Nineteen of 32 specimens were infected (prevalence 59.4\%). Five ethanol-preserved worms were picked from the fins and skin of different hosts. The haptor was cut off, softened and cleared in $120 \mu \mathrm{g} /$ $\mathrm{ml}$ proteinase $\mathrm{K}$. It was then prepared for a microscopy on a slide with a saturated concentration of ammonium picrate in glycerine (Malmberg 1970). The remainder of the body was used for molecular analysis.

The molecular methods used in the present study were as previously described (Ziętara \& Lumme, 2002, 2003; Ziętara et al., 2008). The ITS rDNA fragment encompassing ITS1-5.8S-ITS2 and short fragments of flanking 18S (15 bp) and 28S rRNA (9 bp) genes was amplified with primers ITS1F (5'-GTTTC CGTAG GTGAA CCT- $3^{\prime}$ ) and ITS2R (5'-GGTAA TCACG CTTGA ATC- $\left.3^{\prime}\right)$ and sequenced with two additional primers ITSIR (5'-ATTTG CGTTC GAGAG ACC G- $3^{\prime}$ ) and ITS2F (TGGTG GATCA CTCGG CTC $\left.\mathrm{A}-3^{\prime}\right)$. The PCR program was $3 \mathrm{~min}$ at $95^{\circ} \mathrm{C}$ and 35 cycles of $40 \mathrm{sec}$ at $94^{\circ} \mathrm{C}, 30 \mathrm{sec}$ at $48^{\circ} \mathrm{C}$ and $1 \mathrm{~min}$ at $72^{\circ} \mathrm{C}$, followed by a final elongation step of $7 \mathrm{~min}$ at $72^{\circ} \mathrm{C}$ and an indefinite hold at $4^{\circ} \mathrm{C}$.

The phylogenetic placement of the new species was estimated by aligning the $5.8 \mathrm{~S}+\mathrm{ITS} 2$ segment of the ribosomal DNA with selected sequences published in GenBank. Only predominantly marine lineages of gyrodactylid species were included. The alignment was made using MUSCLE (Edgar, 2004) as implemented in MEGA5 (Tamura et al., 2011) and corrected manually. The phylogenetic tree was estimated from Maximum Composite Likelihood distances (Tamura et al., 2004) using the Neighbor Joining algorithm (Saitou \& Nei, 1987) with the pairwise deletion option. The validity of the branches was evaluated by bootstrapping 500 replicates (Felsenstein, 1985). Bootstrap values lower than $70 \%$ were hidden.

For the species description, the preserved haptors were photographed and measured under a microscope using the measurements of Gusev et al. (1985). Measurements of G. orecchiae Paladini, Cable, Fioravanti, Faria, Cave \& Shinn, 2009 by Paladini et al. (2009) were included for comparison. The North Sea species on Gobius niger remains undescribed (Huyse et al., 2003).

\section{Phylogenetic characterisation using the 5.8S+ITS2 rDNA fragment}

As this report focuses on the new species from Chile and its nearest relatives, we present a phylogeny based 
on 5.8S+ITS2 sequences of marine representatives of Gyrodactylus (Fig. 1), omitting all exclusively freshwater subgenera and species groups, which have already been well analysed by Vanhove et al. (2011). The new species from Chile (JQ045347) clustered with high (98\%) bootstrap support with two geographically distant species. These were G. orecchiae (FJ013097), described from Mediterranean cultured gilthead seabream Sparus aurata (Perciformes: Sparidae) by Paladini et al. (2009), and an undescribed species sequenced and discussed by Huyse et al. (2003) from the black goby Gobius niger (Perciformes: Gobiidae, AY338452) in the North Sea. The relatedness of these two European species was noted by Paladini et al. (2009), but they did not place the species into a wider phylogenetic context. The phylogeographic coverage of this lineage is now extended significantly to include the Southern Hemisphere and the Pacific Ocean.

The complete ITS rDNA (including ITS $1+5.8 \mathrm{~S}$ rDNA+ITS2) sequence is not available for Gyrodactylus sp. from Gobius niger (see Huyse et al., 2003) and therefore the complete ITS segment of the rDNA was aligned only for Gyrodactylus orecchiae and the new species from Chile. The Maximum Composite Likelihood distance was estimated to be $15.4 \%$ between these two species, but it must be stressed that the ITS1+5.8S+ITS2 segments of the rDNA are not optimal for distance estimation, due to problems with the reliable alignment of ITS rDNA, from less related Gyrodactylus species with distances above $10 \%$.

\section{Remarks on the systematic relationships of the new taxon}

Subgeneric position. On the basis of the molecular sequence of the ITS region of the ribosomal DNA, the new species cannot be placed in any of the subgenera previously suggested by Malmberg (1970), which are already rendered poly- and paraphyletic by the inclusion of molecular data (Fig. 1). The Chilean Gyrodactylus species is placed within the mixed basal group of "short ITS" (Cable et al., 1999) species. The "short ITS" clade receives $100 \%$ bootstrap support in Fig. 1 as the sister group of the G. rugiensis, G. micropsi and G. eyipayipi species groups, which are the only marine groups (100\% bootstrap support) among the "long ITS clade", and a sister clade of the subgenus G. (Limnonephrotus) (not demonstrated in Fig. 1, but see the phylogeny of Vanhove et al., 2011).

New species group. The new species clusters with G. orecchiae from the Mediterranean Sea $(100 \%$ bootstrap support) and with an undescribed species on black goby from the North Sea. The three species cluster together with $98 \%$ bootstrap support and are relatively basal in the badly resolved clade $(91 \%$ bootstrap support) of mostly marine, but also some derived freshwater, species. These species have previously been assigned to G. (Mesonephrotus), G. (Metanephrotus) and G. (Paranephrotus), or are not assigned at all. The considerable geographical spread of the three species assigned to this new G. orecchiae species lineage and the systematic diversity of their hosts suggest that a more comprehensive sampling may add numerous new species to this group.

\section{Gyrodactylus chileani $\mathbf{n}$. sp.}

Type-host: Helcogrammoides chilensis (Cancino) (Perciformes: Tripterygiidae); local name 'Trombollito de tres aletas' (three-finned trombollito).

Type-locality: Tidal ponds at Las Cruces, Valparaiso $\left(33^{\circ} 30^{\prime} \mathrm{S}, 71^{\circ} 37^{\prime} \mathrm{W}\right)$, El Tabo, Chile. Sampling date July 22nd, 2009.

Site: Fins and skin.

Type-material: Slides of 5 isolated opisthaptors and 1 complete specimen of G. chileani n. sp. were deposited in Finnish National History Museum in Helsinki University. Holotype: MZH 118095; paratypes: MZH 118096 (complete specimen); MZH 118097-MZH 118100 (isolated haptors).

Molecular data: Definitive identification is based on the nucleotide sequence of the internal transcribed spacers of the nuclear ribosomal DNA. The accession number for the ITS1-5.8S-ITS2 and short flanking segments of $18 \mathrm{~S}$ and $28 \mathrm{~S}$ rDNA from the holotype specimen is JQ045347. The holotype was cut in two, the haptor was mounted on a slide, and the remainder was used for DNA analysis. The ITS rDNA sequence was repeated from all of the five specimens that were measured.

Etymology: The name of the species is derived from the country name, as it is the first Gyrodactylus species described from Chile. 


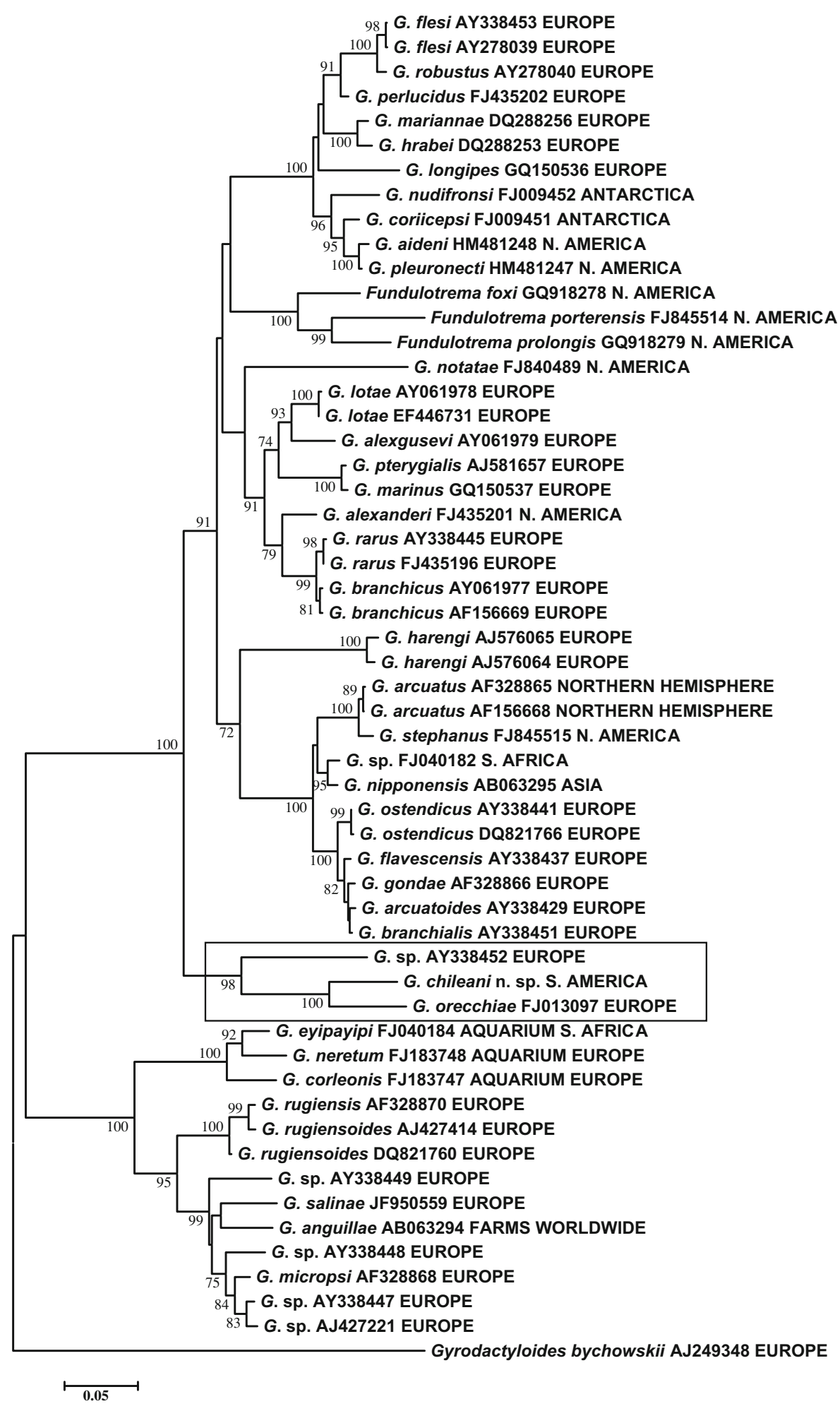


4Fig. 1 Hypothetical phylogenetic position of Gyrodactylus chileani $\mathrm{n}$. sp. based on 5.8S+ITS2 rDNA sequences of marine (or of marine origin) gyrodactylids. Bootstrap support less than $70 \%$ is omitted. Gyrodactylus sp. FJ040182 from Liza richardsonii (Smith); Gyrodactylus sp. AY338452 from Gobius niger (see Huyse et al., 2003); Gyrodactylus sp. AY338449 from Pomatoschistus norvegicus (Collett), a species provisionally called G. cf. longicactylus (see Huyse et al., 2003); Gyrodactylus sp. AJ427221 from Pomatoschistus lozanoi (de Buen), a species provisionally called $G$. cf. micropsi (see Huyse \& Volckaert, 2002); and Gyrodactylus sp. AY338447 from $P$. lozanoi, a species provisionally called $G$. cf. micropsi (see Huyse et al. 2003)

\section{Description (Figs. 2, 3; Table 1)}

[Five specimens were measured. Table 1 contains ranges and mean values of all measurements. Total length of anchor not measured as root is folded.] Shaft 23-27 $\mu \mathrm{m}$; point $17-20 \mu \mathrm{m}$. Ventral bar length 16-20 $\mu \mathrm{m}$, width 3-5 $\mu \mathrm{m}$; membrane length 9-12 $\mu \mathrm{m}$. Dorsal bar length $12-17 \mu \mathrm{m}$, width $2-3 \mu \mathrm{m}$. Marginal hook total length $21-23 \mu \mathrm{m}$; sickle length 4-5 $\mu \mathrm{m}$. Shapes of hamuli resemble those of G. orecchiae and also those of $G$. jirovecii species goup of Eurasian freshwaters, which belong, according to DNA evidence, to subgenus G. (Limnonephrotus). Hamulus roots folded and points extend almost to half length of shafts (Figs. 2A, 3A). Ventral bar with much smaller processes than in G. orecchiae (Figs. 2A, 3B). Dorsal bar with narrow attachments (Fig. 2A). Marginal hooks clearly more delicate than in G. orecchiae; toe triangular in shape, not rhomboid as in G. orecchiae. Shaft of marginal hook points downwards and extends beyond toe. Heel pronounced, but smaller than in G. orecchiae (Figs. 2B, C, 3C).

\section{Discussion}

An overt phylogenetic revision of monogenean parasites of fishes was published by Perkins et al. (2009), with an informative title "Looks can deceive...". This seems to be a general rule among this class of parasites, certainly extending to the specific level among Gyrodactylus spp. With respect to the geographical coverage, the few molecular phylogenetic studies which have been attempted during the last decade are encouraging but far from satisfactory in terms of the strategic planning of a systematic revision (Cable et al., 1999, 2005; Harris \& Cable, 2000; Ziętara et al., 2000, 2002, 2008; Huyse \& Volckaert, 2002, 2005; Ziętara \& Lumme, 2002, 2003, 2004; Boeger et al., 2003; Huyse et al., 2003, 2004, 2006; Matějusová et al., 2003; Huyse \& Malmberg, 2004; LeBlanc et al., 2006; Malmberg et al., 2007; Kuusela et al., 2008; Rokicka et al., 2009; Vanhove et al., 2011). Due to the small fraction of the genus analysed in the above works, little can be said about its systematics. Additionally, a global systematic revision is certainly premature and unwarranted when less than $2 \%$ of the suspected species have been found and described; nevertheless, as the genus appears not to be monophyletic (Kritsky \& Boeger, 2003, Vanhove et al., 2011), some kind of revision is needed. An alternative strategy towards the global systematics of the family Gyrodactylidae could be an extraction of

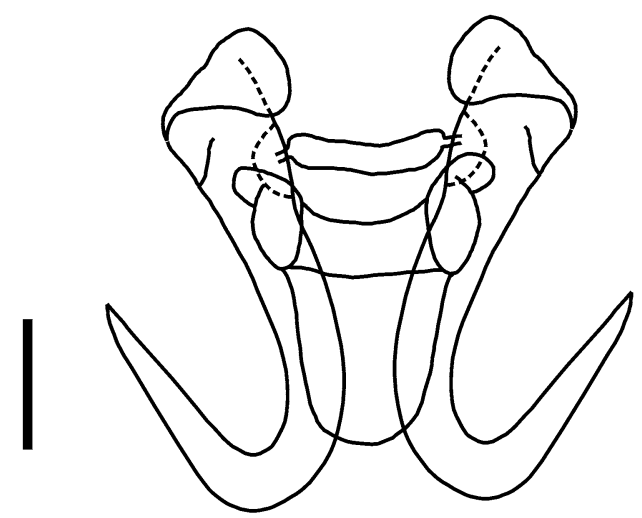

A
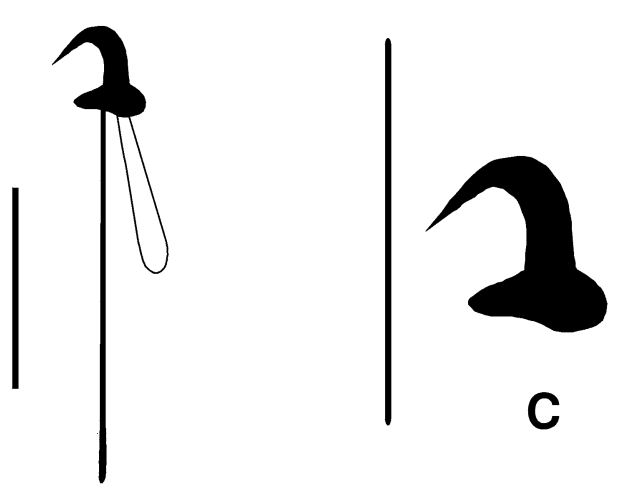

B

Fig. 2 Haptoral morphology of Gyrodactylus chileani n. sp. A. hamuli, dorsal and ventral bars; B. marginal hook; C. marginal hook sickle. Scale-bar: $10 \mu \mathrm{m}$ 

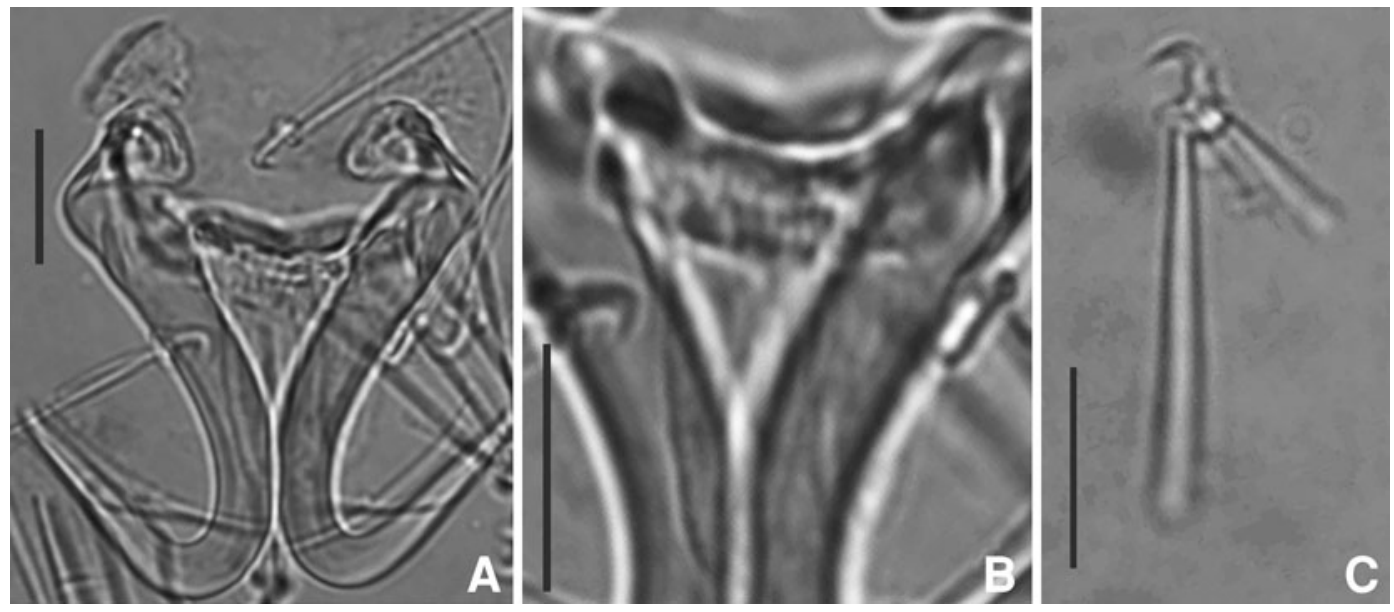

Fig. 3 Photographs of Gyrodactylus chileani n. sp. Holotype. A. hamuli; B. ventral bar; C. marginal hook. Scale-bar: $10 \mu \mathrm{m}$

Table 1 Measurements (in micrometres) of the haptoral hard parts of Gyrodactylus chileani n. sp.

\begin{tabular}{|c|c|c|c|c|c|c|c|c|c|}
\hline \multirow[t]{2}{*}{ Specimens } & \multicolumn{2}{|l|}{ Hamuli } & \multicolumn{2}{|l|}{ Dorsal bar } & \multicolumn{3}{|l|}{ Ventral bar } & \multicolumn{2}{|c|}{ Marginal hook } \\
\hline & $\begin{array}{l}\text { Shaft } \\
\text { length }\end{array}$ & $\begin{array}{l}\text { Point } \\
\text { length }\end{array}$ & Length & Width & Length & Width & $\begin{array}{l}\text { Membrane } \\
\text { length }\end{array}$ & $\begin{array}{l}\text { Total } \\
\text { length }\end{array}$ & $\begin{array}{l}\text { Sickle } \\
\text { length }\end{array}$ \\
\hline All (5) & $23-27(25)$ & $17-20(18)$ & $12-17(14.5)$ & $2-3(2.5)$ & $16-20(18)$ & $3-5(4)$ & 9-12 (11) & $21-23(22)$ & $4-5(4.4)$ \\
\hline Holotype & 27 & 19 & 14 & 2 & 16 & 5 & 12 & 22 & 4.5 \\
\hline G. orecchiae & 21 & 16 & 16 & 2 & 22 & 5 & 11 & 18 & 3.5 \\
\hline
\end{tabular}

Mean values in parentheses. Measurements of G. orecchiae Paladini, Cable, Fioravanti, Faria, Cave \& Shinn, 2009 from Paladini et al. (2009)

well-supported monophyletic lineages based on their DNA, such as the nine lineages visible in present phylogeny, and their further supplementation by morphological characters, but leaving the genus Gyrodactylus as polyphyletic until all of its evolutionary lineages are resolved.

Such a new lineage is revealed in the present study. It consists of only three Gyrodactylus species at present. The hosts of the species belong to the order Perciformes, but the suborders and families differ. These are: Gobius niger (black goby) [suborder Gobioidei: family Gobiidae]; Helcogrammoides chilensis [Blennioidei: Tripterygiidae]; and Sparus aurata (gilthead seabream) [Percoidei: Sparidae]. The parasites on S. aurata were recorded in fish farms from Croatia and Albania (Paladini et al., 2009) or Italy (Paladini et al., 2011b), so it is not known whether the fish is the natural host of Gyrodactylus orecchiae. Considering the species richness of these host families (e.g. Hickey et al., 2009), we may expect that the three parasite species mentioned here are just a small subsample. They are all marine monogeneans and the geographical distance indicates that it is likely that at least the coastal waters of all seas contain related parasite species.

The phylogenetic hypothesis constructed in the present study demonstrates that the marine Gyrodactylus species groups, and in some cases even the species, are quite widely distributed. The G. orecchiae lineage extends from the Mediterranean and North Sea to the South-Eastern Pacific. Gyrodactylus arcuatus Bychowsky, 1933 has been confirmed on three-spined sticklebacks Gasterosteus aculeatus L. from Puget Sound (USA), Iceland, the Mediterranean and Black Seas, the Sea of Japan, Belgium (Cable et al., 1999; Ziętara et al., 2000), Finland (Ziętara et al., 2002, 2008), Norway (Ziętara et al., 2008; Hansen et al., 2012), Poland (Ziętara et al., 2000), Russian Karelia (Ziętara et al., 2008), Sweden (Ziętara et al., 2000; Huyse et al., 2003) and the UK (Cable et al., 1999; Ziętara et al., 2000). Its very close relatives include Gyrodactylus nipponensis Ogawa \& Egusa, 1978 
from Japan (Hayward et al., 2001) and G. stephanus Mueller, 1937 from the NW Atlantic (King \& Cone, 2009) on other host fishes. On three-spined sticklebacks, G. alexanderi Mizelle \& Kritsky, 1967 has also been confirmed using molecular data in both Atlantic (Hansen et al., 2012) and Pacific populations (Rokicka et al., 2009), but G. avalonia Hanek \& Threlfall, 1969 and G. canadensis Hanek \& Threlfall, 1969 await molecular confirmation.

The G. eyipayipi, G. micropsi and G. rugiensis species groups also have a very interesting connection across the equator: G. eyipayipi Vaughan, Christison, Hansen \& Shinn, 2010 has been recorded on greater pipefish Sygnathus acus L. in South African waters (Vaughan et al., 2010), and G. micropsi Gläser, 1974 and G. rugiensis Gläser, 1974 on the gills and fins of Pomatoschistus microps Krøyer, respectively, have been reported from European waters (Ziętara et al., 2002; Huyse et al., 2003, 2006). The related $G$. corleonis Paladini, Cable, Fioravanti, Fiara \& Shinn, 2010 and G. neretum Paladini, Cable, Fioravanti, Fiara \& Shinn, 2010 (Paladini et al. 2010) were found on pipefish Syngnathus typhle L. and S. scovelli Evermann \& Kendall, respectively, from aquaria in Europe. Gyrodactylus salinae Paladini, Huyse \&Shinn, 2011 on Aphasius fasciatus Valenciennes has a Mediterranean distribution (Paladini et al., 2011a), and several species on gobies, provisionally referred to as $G$. cf. micropsi and G. cf. longidactylus, occur in the North Sea (Huyse \& Volckaert, 2002; Huyse et al., 2003). Lastly, G. anguillae Ergens, 1960 is a cosmopolitan species on eels (see Hayward et al. 2001).

It has been already reported that the two Antarctic gyrodactylids, G. coriicepsi Rokicka, Lumme \& Ziętara, 2009 and G. nudifronsi Rokicka, Lumme \& Ziętara, 2009, are related to the European Gyrodactylus fauna, indicating the evolutionary continuum of the marine species in the Northern and Southern Hemispheres (Rokicka et al., 2009). This lineage also accommodates two recently described species, i.e. the European G. longipes Paladini, Hansen, Fioravanti \& Shinn, 2011, reported as a mixed infection with $G$. orecchiae from Sparus aurata in the waters of Bosnia-Herzegovina and Italy (Paladini et al., 2011b), and the North American G. aideni Mullen, Cone, Easy \& Burt, 2010 along with G. pleuronecti Cone, 1981, a species recently tagged by ITS rDNA (Mullen et al., 2010).

So far, the few Gyrodactylus species sampled from the coasts of the Southern Pacific and Southern
Atlantic have been found to have quite close relatives in the species groups studied in the Northern Hemisphere. Connections between the Northern Pacific and Northern Atlantic are even tighter, including common species such as G. arcuatus. This finding supports the hypothesis of Boeger et al. (2003) suggesting the origin of viviparous gyrodactylids in South American waters and a further expansion from that continent via the marine environment. Such a scenario requires a mixing of the marine gyrodactylid fauna as demonstrated in the present paper.

Open Access This article is distributed under the terms of the Creative Commons Attribution License which permits any use, distribution, and reproduction in any medium, provided the original author(s) and the source are credited.

\section{References}

Bakke, T. A., Harris, P. D., \& Cable, J. (2002). Host specificity dynamics: observation of gyrodactylid monogeneans. International Journal for Parasitology, 32, 281-308.

Boeger, W. A., Kritsky, D. C., \& Pie, M. R. (2003). Context of diversification of the viviparous Gyrodactylidae (Platyhelminthes, Monogenoidea). Zoologica Scripta, 32, 437-448.

Cable, J., Harris, P. D., Tinsley, R. C., \& Lazarus, C. M. (1999). Phylogenetic analysis of Gyrodactylus spp. (Platyhelminthes: Monogenea) using ribosomal DNA sequences. Canadian Journal of Zoology, 77, 1439-1449.

Cable, J., Oosterhout, C., Barson, N., \& Harris, P. D. (2005). Gyrodactylus pictae n. sp. (Monogenea: Gyrodactylidae) from the Trinidadian swamp guppy Poecilia picta Regan, with a discussion on species of Gyrodactylus von Nordmann, 1832 and their poeciliid hosts. Systematic Parasitology, 60, 159-164.

Edgar, R. C. (2004). MUSCLE: Multiple sequence alignment with high accuracy and high throughput. Nucleic Acid Research, 32, 1792-1797.

Felsenstein, J. (1985). Confidence limits on phylogenies: an approach using the bootstrap. Evolution, 39, 783-791.

Gusev, A. V., Dubinina, M. N., Pugachev, O. N., Raykova, E. V., Khotenovskiy, I. A., \& Ergens, R. (1985). Opredelitel' parazitov presnovodnykh ryb fauny SSSR, Vol. 2. Paraziticheskie mnogokletochnye. St Petersburg: Nauka, pp. 269-347. (In Russian).

Hansen, H., Jørgensen, A., \& Mo, T. A. (2012). Spin-off from routine parasite diagnostics of Atlantic salmon; first report of Gyrodactylus alexanderi in Norway. The Bulletin of the European Association of Fish Pathologists, 32, 14-18.

Harris, P. D., \& Cable, J. (2000). Gyrodactylus poeciliae n. sp. and G. milleri n. sp. (Monogenea: Gyrodactylidae) from Poecilia caucana (Steindachner) in Venezuela. Systematic Parasitology, 47, 79-85.

Harris, P. D., Shinn, A. P., Cable, J., \& Bakke, T. A. (2004). Nominal species of the genus Gyrodactylus von Nordmann 
1832 (Monogenea: Gyrodactylidae), with a list of principal host species. Systematic Parasitology, 59, 1-27.

Hayward, C. J., Iwashita, M., Ogawa, K., \& Ernst, I. (2001). Global spread of the eel parasite Gyrodactylus anguillae (Monogenea). Biological Invasions, 3, 417-424.

Hickey, A. J. R., Lavery, S. D., Hannan, D. A., Baker, C. S., \& Clements, K. D. (2009). New Zealand triplefin fishes (Family Tripterygiidae): contrasting population structure and mtDNA diversity within a marine species flock. Molecular Ecology, 18, 680-696.

Huyse, T., \& Malmberg, G. (2004). Molecular and morphological comparisons between Gyrodactylus ostendicus n. sp. (Monogenea: Gyrodactylidae) on Pomatoschistus microps (Krøyer) and G. harengi Malmberg, 1957 on Clupea harengus membras L. Systematic Parasitology, 58, 105-113.

Huyse, T., \& Volckaert, F. A. M. (2002). Identification of a hostassociated species complex using molecular and morphometric analysis, with the description of Gyrodactylus rugiensoides $\mathrm{n}$. sp. (Gyrodactylidae, Monogenea). International Journal for Parasitology, 32, 907-919.

Huyse, T., \& Volckaert, F. A. M. (2005). Comparing host and parasite phylogenies: Gyrodactylus flatworms jumping from goby to goby. Systematic Biology, 54, 710-718.

Huyse, T., Audenaert, V., \& Volckaert, F. A. M. (2003). Speciation and host-parasite relationships in the parasite genus Gyrodactylus (Monogenea, Platyhelminthes) infecting gobies of the genus Pomatoschistus (Gobiidae, Teleostei). International Journal for Parasitology, 33, 1679-1689.

Huyse, T., Malmberg, G., \& Volckaert, F. A. M. (2004). Four new species of Gyrodactylus von Nordmann, 1832 (Monogenea, Gyrodactylidae) on gobiid fishes: combined DNA and morphological analyses. Systematic Parasitology, 59, 103-120.

Huyse, T., Pampoulie, C., Audenaert, V., \& Volckaert, F. A. M. (2006). First report of Gyrodactylus spp. (Platyhelminthes: Monogenea) in the western Mediterranean sea: molecular and morphological descriptions. Journal of Parasitology, 92, 682-690.

King, S. D., \& Cone, D. K. (2009). Morphological and molecular taxonomy of a new species of Fundulotrema and comments on Gyrodactylus stephanus (Monogenea: Gyrodactylidae) from Fundulus heteroclitus (Actinopterygii: Cyprinodontiformes) in Nova Scotia, Canada. Journal of Parasitology, 95, 846-849.

Kritsky, D. C., \& Boeger, W. A. (2003). Phylogeny of the Gyrodactylidae and the phylogenetic status of Gyrodactylus Nordmann, 1832 (Platyhelminthes, Monogenoidea). In: Combes, C., \& Jourdanne, J. (Eds) Taxonomie, écologie et évolution desmétazoires parasites. (Livre Hommage à Louis Euzet). Vol. II. Perpignan: Presses Universitaires de Perpignan, pp. 37-58.

Kuusela, J., Ziętara, M. S., \& Lumme, J. (2008). Description of three new European cryptic species of Gyrodactylus Nordmann, 1832 supported by nuclear and mitochondrial phylogenetic characterization. Acta Parasitologica, 53, 120-126.

LeBlanc, J., Hansen, H., Burt, M., \& Cone, D. K. (2006). Gyrodactylus neili n. sp. (Monogenea, Gyrodactylidae), a parasite of chain pickerel Esox niger Lesueur (Esocidae) from freshwaters of New Brunswick Canada. Systematic Parasitology, 65, 43-48.

Malmberg, G. (1970). The excretory systems and the marginal hooks as a basis for the systematics of Gyrodactylus (Trematoda, Monogenea). Arkiv för Zoologi, 23, 1-235.

Malmberg, G., Collins, C. M., Cunningham, C. O., \& Jalali, B. J. (2007). Gyrodactylus derjavinoides sp. nov. (Monogenea, Platyhelminthes) on Salmo trutta trutta L. and G. derjavini Mikailov, 1975 S. t. caspius Kessler, two different species of Gyrodactylus - combined morphological and molecular investigations. Acta Parasitologica, 52, 89-103.

Matějusová, I., Gelnar, M., Verneau, A. O., Cunningham, C. O., \& Littlewood, D. T. J. (2003). Molecular phylogenetic analysis of the genus Gyrodactylus (Platyhelminthes: Monogenea) inferred from rDNA ITS region: subgenera versus species groups. Parasitology, 127, 603-611.

Mullen, A. J., Cone, D. K., Easy, R., \& Burt, M. D. B. (2010). Taxonomy and host-specificity of Gyrodactylus aideni $\mathrm{n}$. sp. and G. pleuronecti (Monogenea: Gyrodactylidae) from Pseudopleuronectes americanus (Walbaum) in Passamaquoddy Bay, New Brunswick. Canada. Systematic Parasitology, 77, 233-239.

Muñoz, G., \& Olmos, V. (2007). Revisión bibliográfica de especies ectoparásitas y hosperados de sitemas acuáticos de Chile. Revista de Biología Marina y Oceanografia, 42, 89-148.

Muñoz, G., \& Randhawa, H. S. (2011). Monthly variation in the parasite communities of the intertidal fish Scartichthys viridis (Blenniidae) from central Chile: are there seasonal patterns? Parasitology Research, 109, 53-62.

Muñoz, G., \& Zamora, L. (2011). Ontogenetic variation in parasite infracommunities of the clingfish Sicyases sanguineus (Pisces: Gobiesocidae). Journal of Parasitology, 97, 14-19.

Paladini, G., Cable, J., Fioravanti, M. L., Faria, P. J., Di Cave, D., \& Shinn, A. P. (2009). Gyrodactylus orecchiae sp. n. (Monogenea: Gyrodactylidae) from farmed populations of gilthead seabream (Sparus aurata) in the Adriatic Sea. Folia Parasitologica, 56, 21-28.

Paladini, G., Cable, J., Fioravanti, M. L., Faria, P. J., \& Shinn, A. P. (2010). The description of Gyrodactylus corleonis $\mathrm{sp} . \mathrm{n}$. and G. neretum sp. n. (Platyhelminthes: Monogenea) with comments on other gyrodactylids parasitising pipefish (Pisces: Syngnathidae). Folia Parasitologica, 57, 17-30.

Paladini, G., Huyse, T., \& Shinn, A. P. (2011a). Gyrodactylus salinae n. sp. (Platyhelminthes: Monogenea) infecting the south European toothcarp Aphanius fasciatus (Valenciennes) (Teleostei, Cyprinodontidae) from a hypersaline environment in Italy. Parasites and Vectors, 4, 100-111.

Paladini, G., Hansen, H., Fioravanti, M. L., \& Shin, A. P. (2011b). Gyrodactylus longipes n. sp. (Monogenea: Gyrodactylidae) from farmed gilthead seabream (Sparus aurata L.) from the Mediterranean. Parasitology International, 60, 410-418.

Perkins, E. M., Donnellan, S. C., Bertozzi, T., Chisholm, L. A., \& Whittington, I. D. (2009). Looks can deceive: molecular phylogeny of a family of flatworm ectoparasites (Monogenea: Capsalidae) does not reflect current morphological classification. Molecular Phylogenetics and Evolution, 52, 705-714. 
Rokicka, M., Lumme, J., \& Ziętara, M. S. (2009). Two Antarctic Gyrodactylus species (Monogenoidea): description and phylogenetic characterization. Journal of Parasitology, 95, 1112-1119.

Saitou, N., \& Nei, M. (1987). The neighbor-joining method: a new method for reconstructing phylogenetic trees. Molecular Biology and Evolution, 4, 406-425.

Tamura, K., Nei, M., \& Kumar, S. (2004). Prospects for inferring very large phylogenies by using the neighbor-joining method. Proceedings of the National Academy of Sciences (USA), 101, 11030-11035.

Tamura, K., Peterson, D., Peterson, N., Stecher, G., Nei, M., \& Kumar, S. (2011). MEGA5: Molecular evolutionary genetics analysis using maximum likelihood, evolutionary distance, and maximum parsimony methods. Molecular Biology and Evolution, 28, 2731-2739.

Vanhove, M. P. M., Snoeks, J., Volckaert, F. A. M., \& Huyse, T. (2011). First description of monogenean parasites in Lake Tanganyika: the cichlid Simochromis diagramma (Teleostei, Cichlidae) harbours a high diversity of Gyrodactylus species (Platyhelminthes, Monogenea). Parasitology, 138, 364-380.

Vaughan, D. B., Christison, K. W., Hansen, H., \& Shinn, A. P. (2010). Gyrodactylus eyipayipi sp. n. (Monogenea: Gyrodactylidae) from Syngnathus acus (Syngnathidae) from South Africa. Folia Parasitologica, 57, 11-15.
Ziętara, M. S., Arndt, A., Geets, A., Hellemans, B., \& Volckaert, F. A. M. (2000). The nuclear rDNA region of Gyrodactylus arcuatus and G. branchicus (Monogenea: Gyrodactylidae). Journal of Parasitology, 86, 1368-1373.

Ziętara, M. S., Huyse, T., Lumme, J., \& Volckaert, F. A. (2002). Deep divergence among subgenera of Gyrodactylus inferred from rDNA ITS region. Parasitology, 124, 39-52.

Ziętara, M. S., Kuusela, J., Veselov, A., \& Lumme, J. (2008). Molecular faunistics of accidental infections of Gyrodactylus Nordmann, 1832 (Monogenea) parasitic on salmon Salmo salar L. and brown trout Salmo trutta L. in NW Russia. Systematic Parasitology, 69, 123-135.

Ziętara, M. S., \& Lumme, J. (2002). Speciation by host switch and adaptive radiation in a fish parasite genus Gyrodactylus (Monogenea: Gyrodactylidae). Evolution, 56, 2445-2458.

Ziętara, M. S., \& Lumme, J. (2003). The crossroads of molecular, typological and biological species concepts: two new species of Gyrodactylus Nordmann, 1832 (Monogenea, Gyrodactylidae). Systematic Parasitology, 55, 39-52.

Ziętara, M. S., \& Lumme, J. (2004). Comparison of molecular phylogeny and morphological systematics in fish parasite genus Gyrodactylus Nordmann, 1832 (Monogenea, Gyrodactylidae). Zoologica Poloniae, 49, 5-28. 